\title{
КОНЦЕПЦИЈА И ПРАКСА МЕТОДИЧКИХ ПРЕДМЕТА НА КАТЕДРИ ЗА БИБЛИОТЕКАРСТВО И ИНФОРМАТИКУ НА ФИЛОЛОШКОМ ФАКУЛТЕТУ УНИВЕРЗИТЕТА У БЕОГРАДУ
}

\section{Сажетак}

Катедра за библиотекарство и информатику на Филолошком факултету Универзитета у Београду током дугогодишњег деловања настоји да прошири наставно искуство и развије наставне планове који ће истовремено задовољити потребе студената и испратити реформе у образовању. Од доношења Закона о високом образовању 2005, 2006, 2008. и посебно 2009. године, Катедра је прихватајући болоњску декларацију креирала нове предмете. На академским студијама другог степена - мастеру, посебна пажња посвећена је методичким предметима. Концепција и пракса предмета Библиотека у настави и Методичка пракса - хоспитовање представљени су кроз резултате истраживања спроведеног међу мастер студентима који су похађали ове курсеве током школске 2016/17. године

Кључне речи: Катедра за билиотекарство и информатику, Библиотека у настави, Методичка пракса, мастер студије, студенти, истраживање

\section{Методички предмети на Катедри за библиотекарство и информатику}

Катедра за библиотекарство и информатику на Филолошком факултету Универзитета у Београду од свог оснивања, од 1990. године,

1 Филолошки факултет, Студентски трг 3, 11000 Београд

dragana.gr@gmail.com

2 Овај рад је настао у оквиру пројекта бр. 178029 Министарства за просвету, науку и технолошки развој Републике Србије, Књиженство, теорија и историја женске књижевности на српском језику до 1915. године. 
до данас развија наставне планове који теже да истовремено задовоље потребе студената и испрате реформе на свим нивоима образовања. ${ }^{3}$ Од доношења Закона о високом образовању 2005, 2006, 2008. и посебно 2009. године, Катедра је прихватајући болоњску декларацију креирала нове предмете. На реформисање наставних програма утицао је и најновији „Закон о основама система образовања и васпитања“. Наиме, према овом закону за рад у школи неопходно је 30 ЕСП бодова који припадају групи предмета из области психологије, педагогије и методике наставе (ППМ предмети) и 6 ЕСПБ праксе, ${ }^{4}$ што је минимум захтева у складу са Европским системом преноса бодова. У жељи да усклади наставни план и програм са најновијим одредбама овог закона, на Катедри за библиотекарство и информатику посебна пажња посвећена је изборним методичким предметима: Информациона и медијска писменост у школској библиотеци, Информациона и медијска писменост у науци, Библиотека у настави и Методичка пракса - хоспитовање.

Предмети Библиотека у настави и Методичка пракса су превасходно усмерени на указивање значаја укључивања библиотеке у наставни процес и оспособљавања студената за рад са ученицима у школском окружењу. Основна одлика и новина која их карактерише је интерактивна метода рада на часовима и практична настава.

Циљ ових предмета је да студенти:

- активно учествују у раду,

- стекну професионална знања и искуства,

- упознају различите облике рада,

- критички посматрају, вреднују и унапређују свој рад,

- формирају и развију сопствени методички стил,

- уоче разлике у раду са млађим и старијим ученицима,

- практично примене стечено теоријско знање и да се

- адаптирају на радно окружење.

Колико смо у томе успешни? У жељи да се добије одговор на ово питање, спроведено је истраживање.

3 Министарство просвете и спорта, Квалитетно образовање за све: изазови реформе образовања у Србији (Београд, 2004); Службени гласник Републике Србије, Закон о високом образовању, 76/2005.

4 Службени гласник Републике Србије, Закон о основама образовања и васпитања, бр. 72/2009, 88/2017 (члан 142). 


\section{Истраживање}

- Методологија рада и узорак варијабли

Узорак испитаника чинили су мастер студенти који су током школске 2016/2017. године похађали курсеве Библиотека у настави и Методичка пракса. Наставом из ових предмета желимо да омогућимо студентима да повежутеоријскознање и практично искуство, формирају основу за даљи рад, а самим тим да студенти развију позитиван став према изабраним предметима - што уједно представља полазне хипотезе истраживања. Ова два предмета у току наведене године похађало је 268 студената, од којих је 239 учествовло у анкети ${ }^{5}$ која је дистрибуирана путем мејла и на часовима. Анкета је била анонимна, а у интерпретацији резултата нисмо делили студенте према полу, годинама, ни завршеним основним академским студијама. Упитници, наменски састављени за потребе овог истраживања, обухаватали су девет тврдњи које су се односиле на квалитет предмета (вредновање теоријске и практичне наставе, програма и квалитет рада и примена стеченог знања). Од инструмената примењена је скала процене, ставови испитаника процењивани су путем петостепене скале Ликертовог типа, која садржи следеће категорије одговора: 1 - упоште се не слажем, 2 - углавном се не слажем, 3 - не знам, неодлучан сам, 4 -углавном се слажем и 5 - потпуно се слажем.

- Резултати

1. Пре похађања методичке наставе на Катедри за библиотекарство и информатику, имао сам знања из области библиотекарства

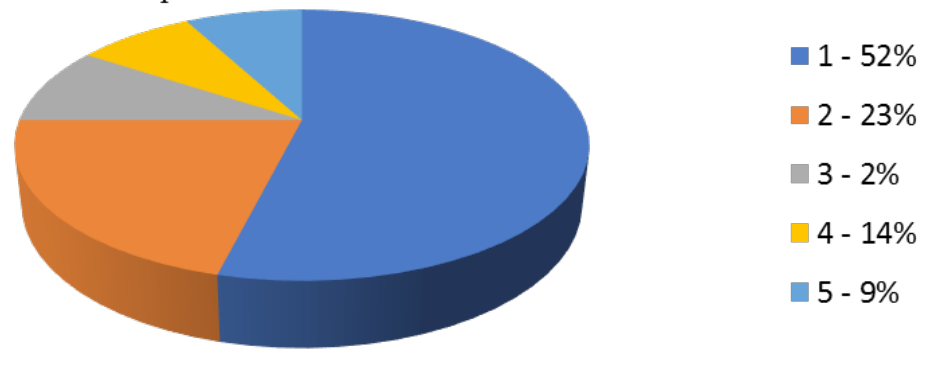

5 Од 206 студената колико је одбарало и слушало предмет Библиотека у настави у наведеној години 185 је одговорило, а од 62 студента која су похађала Методичку праксу одговорило је 54. 
Катедра за библиотекарство и информатику је интердисциплинарна - курсеве који припадају групи изборних предмета могу да бирају и студенти других студијских група. Управо прва тврдња открива да предмете Библиотека у настави и Методичка пракса више похађају студенти којима библиотекарство није примарна научна област.

2. На мастер студијама први пут сам се сусрео са методиком наставе

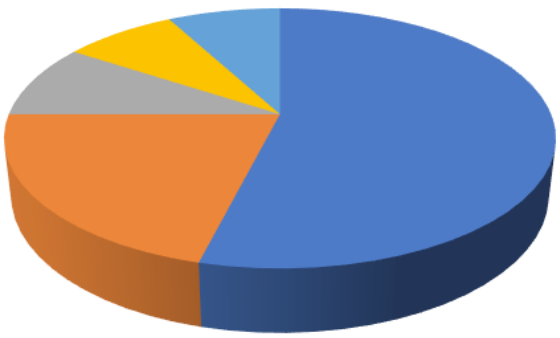

$1-8 \%$

$2-18 \%$

- $3-1 \%$

$\square-28 \%$

$-5-44 \%$

Чак $44 \%$ испитаника се први пут сусреће са методиком наставе на мастеру, што може указати и на потребу да овакви предмети буду више заступљени на основним студијама.

3. Задовољан сам увођењем изборних методичких предмета на Катедри за библиотекарство и информатику

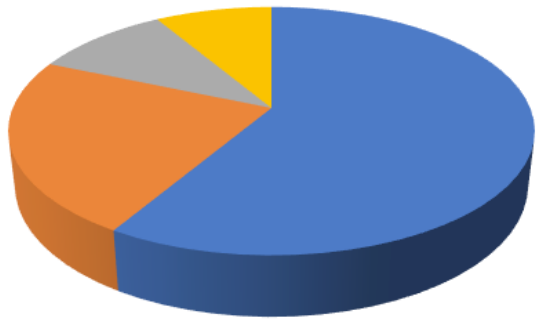

$\square-2 \%$

- 2 - $3 \%$

- 3 - $14 \%$

$\square-47 \%$

ㄷ $5-34 \%$ 
4. Задовољан сам добијеним знањем/искуством

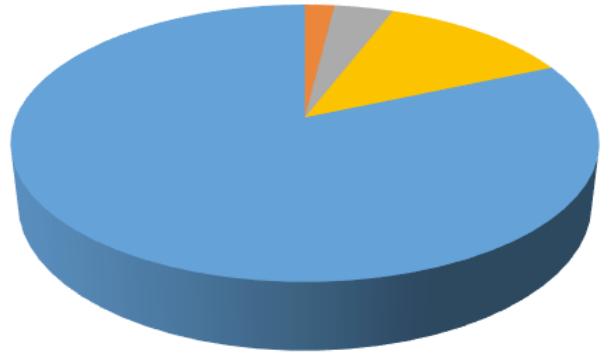

$-1-0 \%$

$-2-2 \%$

$-3-4 \%$

$4-13 \%$

- $5-84 \%$

Предмети пружају могућност да се и студенти који долазе из других области усавршавају и стекну практична и стручна знања из библиотекарства. Добијени одговори иду у прилог концепцији и реализацији наставе.

5. Предмет ми је омогућио да сагледам важност школске библиотеке у васпитно образовном процесу

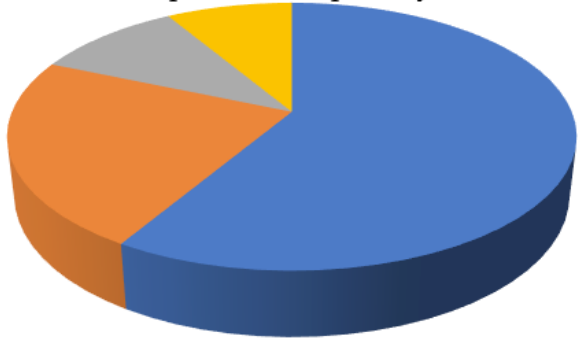

- $1-0 \%$

- $2-1 \%$

$-3-6 \%$

$4-18 \%$

$5-75 \%$

Како је библиотека саставни део васпитно образовног процеса и њено деловање у великој мери почива на сарадњи наставног и стручног кадра, охрабрује податак да 75\% испитаника увиђа њен значај. Овоме су свакако допринели и школски библиотекари, који током обављања праксе имају улогу ментора. 
6. Оспособљен сам да у непосредном васпитно-образовном раду препознам различите концепције рада

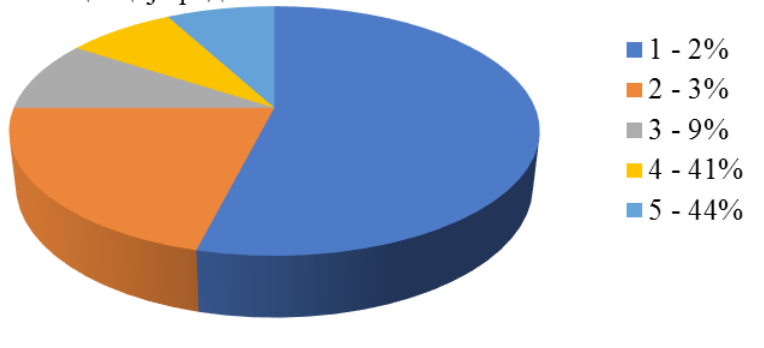

Студенти, посебно током праксе, имају прилику да присуствују часовима у нижим и вишим разредима како би се упознали са различитим облицима рада прилагођеним узрасту, потребама и интересовањима ученика. Велики број испитаника је препознао предности овакве организације наставе.

7. Потребно је више оваквих методичких предмета

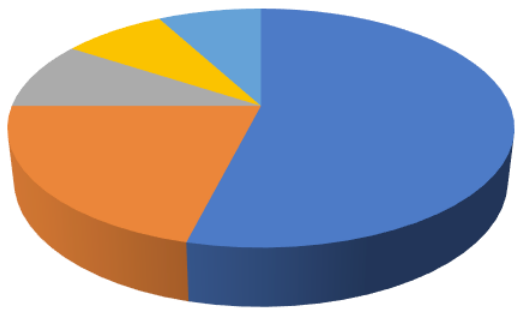

$-1-1 \%$

$=2-3 \%$

- $3-10 \%$

$-4-32 \%$

$-5-54 \%$

Добијени одговори потврђују ставове студената изнетих у другој тврдњи. 
8. Стечено знање омогући ће ми да лакше нађем посао

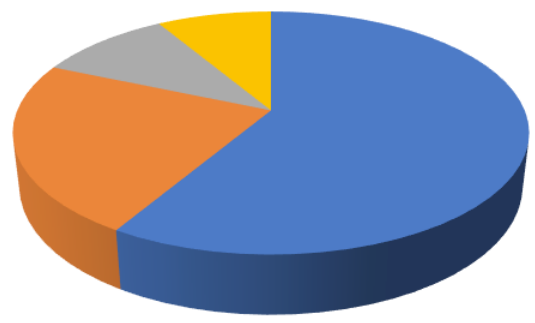

- $1-4 \%$

$-2-18 \%$

$\square-21 \%$

$\square-43 \%$

$-5-14 \%$

9. Стечено знање користиће ми у будућем професионалном ангажовању

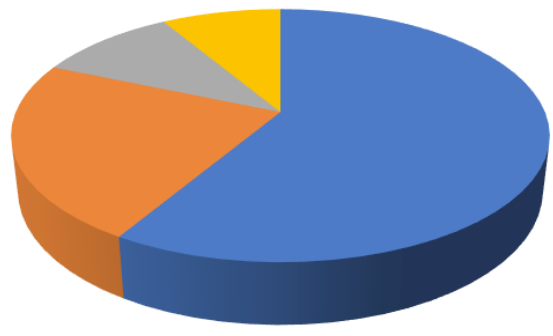

- $1-0 \%$

$-2-1 \%$

$-3-6 \%$

$4-21 \%$

$5-72 \%$

Приликом дефинисања исхода учења, неопходно је је сагледати и које су то компетенције за обављање посла неопходне. ${ }^{6}$ Велики број студената види предности које похађање наставе из ових предмета доноси и верују да ће у раду моћи да примене научено (72\% испитаника), нажалост само 14\% испитаника сматра да ће им то помоћи у запошљавању.

\section{Закључна разматрања}

Иако је учествовање у истраживању добровољно, одзив је био велики, те се добијени одговори могу сматрати релевантним. Циљ анкете био је да се испитају ставови студената према изборним

6 Martina Vukasović, Razvoj kurikuluma u visokom obrazovanju (Beograd: Alternativna akademska obrazovna mreža, 2006), 78. 
методичким предметима. Одговори потврђују полазне хипотезе - да су предмети Библиотека у настави и Методичка пракса неопходни студентима у циљу стицања и развијања стручних компетенција потребних за рад у школи, односно школској библиотеци. Упркос чињеници да већини испитаника библиотекарство није примарни избор студирања (тврдња бр. 1), показују позитиван однос према наведеним предметима, према школи и библиотеци као њеном саставном делу. Библиотека својим фондом и услугама траба да подржи одвијање наставе и код ученика изгради позитиван став према књизи и читању, те је важно да студенти - будући библиотекари и наставници препознају библиотеку као важан чинилац у раду школе.

Анализа анкете открива да је Катедра за библиотекарство и информатику увођењем ових изборних методичких предмета у великој мери успела да задовољи потребе и интересовања студената. Управо највећи степен слагања у ставовима студената је у тврдњи бр. 3 - Задовољан сам добијеним знањем/искуством (84\% испитаника). Поштујући улогу студената у академској заједници, треба омогућити вредновање предмета и наставе од стране студената у циљу побољшања целокупног наставног процеса. Пожељно је оваква истраживања спроводити чешће и у већем обиму, како би се у складу са повратним информацијама вршила ревизија постојећих наставних планова.

\section{Литература:}

Министарство просвете и спорта. Квалитетно образовање за све: изазови реформе образовања у Србији. Београд, 2004.

Службени гласник Републике Србије. Закон о високом образовању, 76/2005.

Службени гласник Републике Србије. Закон о основама образовања и васпитања, 72/2009, 88/2017.

Vukasović, Martina. Razvoj kurikuluma u visokom obrazovanju. Beograd: Alternativna akademska obrazovna mreža, 2006. 


\section{Dragana Grujić}

THE CONCEPT AND PRACTICE OF THE METHODOLOGICAL SUBJECTS AT THE DEPARTMENT OF LIBRARY

AND INFORMATION SCIENCE AT THE FACULTY OF PHILOLOGY, UNIVERSITY OF BELGRADE

\section{Summary}

Department of Library and Information Science at the Faculty of Philology, University of Belgrade, during the years of work seeks to expand the educational experience and develop curricula that will meet the needs of students and at the same time accompany reforms in education. Since the adoption of the law on higher education in 2005, 2006, 2008 and especially in 2009, with the implementation of the Bologna Declaration, Department has created new subjects. On the academic studies of second degree - master, special attention was paid to the subjects from methodological field. The concept and practice of the subject Library teaching and Methodical practice - demonstration classes are presented through the results of a survey conducted among the master students who have attended these courses during the 2016/17 academic year.

Key words: Department for Librarianship and Information Science, Library teaching, Methodical practice, master studies, students, Likert scale, research. 